\title{
PEMBUATAN TES DAN NORMA KEBUGARAN JASMANI UNTUK ANAK USIA DINI (4-6) TAHUN DI PROVINSI DIY
}

\section{CONSTRUCTING A TEST AND STANDARD OF PHYSICAL FITNESS FOR 4-6 YEARS OLD CHILDREN IN DIY}

\author{
Bertika Kusuma Prastiwi, Suharjana \\ SMK Negeri 4 Klaten, Universitas Negeri Yogyakarta \\ bertikakusuma@gmail.com, suharjanafikuny@yahoo.com
}

\begin{abstract}
Abstrak
Penelitian ini bertujuan untuk mengembangkan model tes kebugaran jasmani untuk anak usia dini (4-6 tahun) yang valid dan reliabel, yang terdiri dari kekuatan otot, ketahanan otot, daya tahan aerobik, dan fleksibilitas. Penelitian ini merupakan research and development dengan pendekatan survei melalui tes pengukuran. Penelitian ini diawali dengan pembuatan draf model, validasi model oleh para ahli. Tahap selanjutnya adalah uji coba skala kecil terhadap 10 siswa dan uji coba skala besar terhadap 20 siswa. Uji coba skala kecil dilakukan di satu Taman Kanak-kanak (TK). Uji skala besar dilaksanakan di dua TK. Uji lapangan utama terhadap 310 siswa yang dilakukan di 15 TK di DIY yang ditetapkan menggunakan cluster sample technique. Validitas menggunakan face validity dan reliabilitas menggunakan test-retest. Teknik pengambilan data tes menggunakan test battery. Teknik analisis data menggunakan uji deskriptif, uji validitas dan reliabilitas menggunakan SPSS 16, dan z skor untuk menyamakan satuan. Hasil penelitian dan pengembangan berupa model tes dan norma kebugaran jasmani untuk anak usia dini (4-6 tahun) berupa buku pedoman tes kebugaran jasmani yang telah divalidasi ahli. Validitas tes 0,982 dan reliabilitas tes 0,930 menggunakan taraf signifikan 0,01 . Model tes kebugaran jasmani yang disusun dinyatakan layak karena valid dan reliabel. Hasil pengembangan model tes kebugaran jasmani untuk anak usia dini (4-6 tahun) digunakan sebagai pedoman guru PAUD utamanya di TK dalam pemberian nilai dan perkembangan kebugaran jasmani di TK, yakni pada usia 4-6 tahun.
\end{abstract}

Kata kunci: model tes dan norma kebugaran jasmani, anak usia dini (usia 4-6 tahun).

\begin{abstract}
This research in aimed to construct a valid and reliable physical fitness test for children of 4-6 years old, consisting of muscular strength, muscular endurance, aerobic endurance, and flexibility. This research is a research and development with a survey approach through a measurement test. The research began with the construction of the model draft, validated through expert judgment. The next process was preliminary field testing was carried out at a kindergarten and the main field testing at two kindergartens. The operational field testing involved 310 children carried out at 15 kindergartens in DIY. The sample was established using the cluster sampling technique. The validity used was face validity and the reliability was test-retest. The data were collected using a battery test. The analysis used a descriptive test, and the validity and reliability used SPSS 16 and $z$ score. The result of this research and development is a physical fitness instruction test and standards of physical fitness for children of 4-6 years old. The result of the validity testing is 0.982 and reliability is 0.930 with $r$ significant 0.01. The physical fitness test for children of 4-6 years old is appropriate since the data are valid and reliable. The result of the physical fitness test for children of 4-6 years old is used as a guide for teachers of kindergartens in giving scores and physical fitness growth of kindergarten students of 4-6 years old.
\end{abstract}

Keywords: the test and standard physical fitness, children of 4-6 years. 


\section{Pendahuluan}

Pendidikan anak usia dini (PAUD) banyak berdiri di daerah perkotaan hingga pedesaan. Pendidikan ini menggunakan pendekatan bermain kepada anak, sehingga anak tidak merasa dipaksa untuk belajar di bangku sekolah. Metode yang digunakan dalam pembelajaran ialah bermain sambil belajar dan bersosialisasi terhadap orang lain.

Tujuan berdirinya PAUD untuk melatih kognitif, afektif, dan psikomotor anak sejak dini menggunakan metode bermain. Aspek yang diintegrasikan dalam bermain adalah psikomotor didukung dengan aspek lain. Psikomotor mempunyai hubungan erat dengan gerak dan kebugaran jasmani anak. Konsep kebugaran jasmani kurang diterapkan oleh guru-guru yang mengajar di PAUD karena guru PAUD berasal dari disiplin ilmu umum tanpa disertai kemampuan mengajarkan fisik motorik untuk kebugaran. Aspek yang dikembangkan di PAUD mengarah pada kognitif dan afektif sedangkan aspek motorik kurang dikembangkan.

Pengembangan aspek motorik yang kurang mengakibatkan anak memiliki tingkat kebugaran berbeda-beda, cara membedakan anak yang bugar maupun tidak bugar, aktif atau tidak aktif ditentukan oleh beberapa masalah. Masalah pertama adalah definisi dari kebugaran jasmani yang mengalami perubahan dari tahun ke tahun. Faktor penentu utama dari tes kebugaran jasmani jaman dahulu dengan penilaian atletik dan kemampuan motorik, tetapi sekarang ini faktor penentu tingkat kebugaran jasmani berfokus pada kesehatan yang berhubungan dengan komponen kebugaran jasmani yang terdiri dari; daya tahan kardiovaskuler, kekuatan otot, daya tahan otot, fleksibilitas, dan komposisi tubuh.

Masalah kedua, tes kebugaran jasmani untuk anak usia dini (AUD) belum ada, sehingga guru PAUD mengalami kesulitan untuk melakukan tes kebugaran jasmani. Penilaian kebugaran hanya bersifat subjektif yang dilihat dari segi kesehatan, yaitu anak sakit atau sehat. Pengklasifikasian mengenai kebugaran anak memerlukan norma kebugaran jasmani untuk AUD dan perlu adanya penelitian mengenai hal tersebut. Norma ditentukan dengan pengelompokan kondisi kebugaran jasmani AUD dari yang baik maupun kurang. Sampel dari sebuah populasi dapat digunakan untuk menentukan norma secara umum. Tingkat kebugaran jasmani seseorang ditentukan oleh kondisi fisik dan kesehatan. Hasil dari tes seorang anak cenderung membandingkan standar kebugaran bukan hasil jika dibandingkan dengan anak yang lain. Kondisi kebugaran anak berbeda-beda baik secara individu dan tempat tinggal, anak dapat dikatakan lebih bugar dalam wilayahnya namun belum tentu di wilayah lain dalam kategori bugar, karena perbedaan segi geografis dan aktivitas sehari-hari.

Pandangan umum masyarakat bahwa anak yang sering melakukan aktivitas lebih bugar daripada anak yang tidak beraktivitas. Kebugaran dan aktivitas fisik saling berkaitan, secara umum anak dilahirkan sehat dan bugar, jika dilihat dari segi individual. Anak tumbuh dan berkembang kemudian mengalami peningkatan kebugaran dan berubah selama fase pertumbuhan. Kondisi kebugaran jasmani anak sesuai dengan lingkungan dan iklim tempat tinggal.

Tujuan dari mengajarkan kebugaran jasmani pada anak bukan berorientasi pada hasil tetapi lebih mengutamakan proses. Pengalaman anak dalam beraktivitas mengajarkan mengenai penggunaan tenaga yang bermanfaat, belajar bertanggung jawab, dan bergaya hidup sehat. Pelajaran yang didapat dari kehidupan seharihari untuk mendapatkan kebugaran jasmani yang baik adalah aktivitas fisik atau olahraga 25 kali seminggu selama 30-45 menit disamping pembelajaran fisik motorik di sekolah.

Berdasarkan hasil pengumpulan informasi dari beberapa guru PAUD di Provinsi DIY (Daerah Istimewa Yogyakarta) terdapat beberapa masalah yang berhubungan dengan kebugaran jasmani untuk AUD. Masalah utama yaitu kurangnya pembelajaran motorik di PAUD oleh guru yang bertujuan untuk meningkatkan kebugaran jasmani.

Konsep kebugaran jasmani belum tertanam pada guru PAUD. Pembelajaran gerak masih bersifat umum, guru belum dapat membedakan konsep kebugaran jasmani dan sakit yang terjadi pada AUD. "Kebugaran adalah hal sehat dan segar (tentang badan), jasmani adalah tubuh, badan sebagai lawan rohani" (KBBI, 2007, p.115). Kebugaran jasmani jika dilihat dari segi waktu pencapaiannya membutuhkan proses lama, untuk mendapatkan kebugaran jasmani yang baik dan perlu latihan secara terus menerus. "Sakit adalah berasa tidak nyaman di tubuh atau bagian tubuh karena menderita sesuatu" (KBBI, 2007, p.214). Sakit merupakan kondisi klinis seseorang yang perlu suatu penanganan medis. 
Komponen-komponen kebugaran jasmani belum diketahui secara mendalam oleh guru PAUD. Pembelajaran yang berdasar pada komponen kebugaran jasmani hasilnya akan maksimal untuk AUD. Kurikulum yang digunakan di PAUD utamanya Taman Kanak-kanak (TK) terdapat materi motorik kasar dan halus, materi tersebut berdasarkan penggabungan mengenai gerak reptilia, mamalia, dan manusia.

Proses pembelajaran motorik di PAUD yang digabungkan dengan materi lain yang bertujuan untuk meningkatkan dan memelihara kebugaran jasmani. Pembelajaran yang dilakukan setiap hari di PAUD sadar maupun tidak sadar selama proses pembelajaran dari awal masuk anak dibariskan, anak bernyanyi sambil bertepuk tangan, dan "ber-yel-yel", inti pembelajaran adalah anak melakukan aktivitas yang berorientasi pada konsep bermain, sampai akhir pembelajaran anak telah melaksanakan aktivitas jasmani. Namun sebaliknya, kegiatan motorik anak-anak di luar sekolah sangat kurang karena adanya game-game elektronik yang tidak memerlukan aktivitas motorik, akibatnya kebugaran anak menurun.

Masalah lain adalah alat-alat yang ada di PAUD kurang diketahui fungsi atau penggunaannya oleh guru PAUD, terutama alat yang berhubungan dengan motorik, contoh; tangga monyet untuk bergelayutan dan memanjat tujuannya melatih kekuatan dan ketahanan otot, garis lintasan, dan lapangan rumput maupun halaman sekolah dapat digunakan untuk melatih daya tahan aerobik dan peralatan lainnya.

Permasalahan-permasalahan tersebut di atas menjadi acuan peneliti untuk membuat tes kebugaran jasmani untuk AUD. Proses pembelajaran motorik yang dilaksanakan di PAUD belum ada acuan tes, maka peningkatan kebugaran belum dapat diketahui. Tes kebugaran jasmani untuk AUD (4-6 tahun) perlu dibuat untuk mengetahui tingkat kebugaran jasmani AUD. Tes kebugaran jasmani yang sudah ada diperuntukkan untuk usia 6-19 tahun (Depdiknas, 1999, p.1), maka tidak tepat apabila digunakan untuk AUD. Tes yang dibuat mempertimbangkan pemanfaatan alat-alat yang ada di PAUD, mudah, sederhana, murah, aman, dan menarik.

Tes yang dibuat perlu adanya norma untuk mengetahui kondisi kebugaran jasmani anak. Tes kebugaran jasmani AUD diharapkan bermanfaat untuk guru PAUD dan orang tua agar mengetahui tingkat kebugaran jasmani anak. Hasil dari tes berguna untuk guru PAUD dan orang tua dalam memberikan latihan atau aktivitas jasmani untuk meningkatkan kebugaran jasmani. Anak yang mempunyai kebugaran jasmani kurang maka diberikan latihan yang lebih, jika sudah baik maka perlu dipertahankan atau ditingkatkan, hasil tes dapat digunakan sebagai portofolio kebugaran jasmani anak.

Berdasarkan penjelasan di atas, maka rumusan masalahnya adalah "Apakah tes kebugaran jasmani AUD (4-6 tahun) dalam mengukur tingkat kebugaran AUD?"

Tujuan penelitian yang ingin dicapai adalah untuk membuat tes dan norma kebugaran jasmani untuk AUD (4-6 tahun) yang valid dan reliabel berdasarkan komponen kebugaran jasmani sehingga dapat digunakan untuk mengetahui tingkat kebugaran jasmani AUD (46 tahun). Penelitian ini bertujuan untuk menyusun buku petunjuk tes kebugaran jasmani untuk AUD (4-6 tahun). Penelitian ini menggunakan pendekatan pengembangan karena akan mengembangkan tes dan norma kebugaran jasmani dengan memodifikasi tes kebugaran jasmani yang sudah ada.

Tes, pengukuran, dan evaluasi merupakan tiga istilah yang berbeda namun saling berhubungan. Tes adalah sebuah instrumen yang dipakai untuk memperoleh informasi tentang seseorang atau objek (Lutan, 2001, p.21). Tes yang dimaksud adalah tes yang memenuhi syarat validitas, reliabilitas, objektivitas, diskriminitas, dan praktibilitas. Validitas adalah kriteria yang paling penting untuk mempertimbangkan ketika mengevaluasi tes karena validitas mengacu pada sejauh mana tes benar-benar mengukur masalah dalam pengukuran. Reliabilitas suatu tes adalah taraf sampai dimana suatu tes mampu menunjukkan konsisten hasil pengukurannya yang diperlihatkan dalam taraf ketetapan dan ketelitian hasil. Objektivitas, suatu tes memiliki objektivitas tinggi jika dua atau lebih orang bisa mengelola tes dan kelompok yang sama, serta memperoleh hasil kira-kira sama. Diskriminitas, tes yang baik harus dapat membedakan kemampuan siswa sesuai dengan tingkat keterampilan dan kepandaian siswa sehingga dapat membedakan siswa yang berkemampuan jelek, cukup, baik, dan baik sekali. Praktibilitas, adalah pertimbangan yang bersifat praktis dan dapat mempengaruhi tes meliputi; waktu, biaya, kemudahan pengadministrasian, dan kemudahan dalam penafsiran. Tes yang baik adalah memenuhi syarat valid, reliabel, objektif, diskriminatif, dan praktibilitas, selain syarat tersebut terdapat syarat novel tes. Jenis tes harus disesuaikan dengan karakter subjek yang akan 
diteliti, didasarkan pada umur, jenis kelamin, ataupun lembaga. Jenis tes harus disesuaikan dengan karakter subjek. Menurut Lutan (2001, p.21) "pengukuran ialah proses pengumpulan informasi”. Menurut Lutan (2001, p.22) "evaluasi merupakan proses penentuan nilai atau kelayakan data yang terhimpun". Ranah yang diukur dalam pendidikan jasmani atau lingkup olahraga, pengukuran dilakukan pada beberapa ranah, (Suyanto, 2003, p.52): (1) pengukuran ranah kognitif, pengukuran pada ranah ini dilakukan untuk mengukur pengetahuan yang dimiliki sehubungan dengan pengembangan dan cara mempertahankan kesegaran jasmani, cara pencegahan cedera. (2) pengukuran ranah afektif, pengukuran pada ranah ini mengukur minat, perhatian, sikap, perasaan, dan nilai dalam hubungannya dengan aktivitas fisik yang bermakna. (3) pengukuran ranah psikomotor, pengukuran dalam ranah ini mengukur keterampilan motorik, perkembangan motorik, dan kesegaran jasmani.

Kebugaran jasmani menurut Irianto (2004, pp.2-3) secara umum, yang dimaksud dengan kebugaran jasmani adalah fisik (physical fitnes), yakni kemampuan seseorang melakukan kerja sehari-hari secara efisien tanpa timbul kelelahan yang berlebihan sehingga masih dapat menikmati waktu luangnya. Komponen kebugaran jasmani berkaitan dengan kesehatan menurut Heru (2008, p.264), kebugaran jasmani terdiri dari komponen-komponen yang dikelompokkan menjadi kelompok yang berhubungan dengan kesehatan (health related physical fitness) dan kelompok yang berhubungan dengan ketrampilan (skill related physical fitness). Komponen kebugaran jasmani yang akan diteliti yaitu kebugaran jasmani yang berhubungan dengan kesehatan yaitu kekuatan otot, ketahanan otot, daya tahan aerobik dan fleksibilitas, keempat komponen kebugaran jasmani tersebut digunakan karena sudah mewakili aktivitas motorik AUD. Faktor-faktor yang mempengaruhi kebugaran jasmani adalah; umur, jenis kelamin, somatotipe, atau bentuk badan, keadaan kesehatan, gizi, berat badan, tidur atau istirahat, dan kegiatan jasmaniah. Faktor utama yang berhubungan dan memengaruhi batas waktu aktivitas adalah perasaan lelah. Aktivitas fisik yang lama banyak ditentukan oleh aktivitas kerja sistem jantung dan peredaran darah di dalam menyalurkan oksigen ke otot-otot yang sedang aktivitas dan juga ditentukan oleh kapasitas kerja paru di dalam mengambil oksigen dan mengeluarkan karbondioksida, sehingga kebu- tuhan oksigen cukup untuk pembakaran karbohidrat yang menghasilkan energi untuk gerak. Seseorang yang memiliki kebugaran jasmani yang baik dalam melakukan aktivitas fisik tidak mudah lelah atau masih mempunyai kemampuan untuk meneruskan aktivitasnya meskipun dalam keadaan lelah. Berdasarkan uraian di atas maka perlu memodifikasi alat dan tes kebugaran jasmani sesuai dengan karakteristik AUD sehingga menghasilkan suatu tes dan norma kebugaran jasmani untuk anak usia dini 4-6 tahun.

Penyusunan instrumen akan mudah jika memperhatikan tentang hal-hal yang akan diukur, maka definisi operasional variabel penelitian sebagai berikut: (1) kebugaran jasmani AUD adalah menunjukkan kemampuan anak dalam melakukan kegiatan sehari-hari tanpa mengalami kelelahan yang berarti dan masih bisa melakukan kegiatan lain, (2) kekuatan otot, kemampuan AUD untuk menggunakan otot tangan dan kaki untuk berjalan menuju titik tertentu. Anak dengan posisi merangkak, tangan dan kaki sebagai tumpuan di garis star berlomba merangkak menuju finis untuk memasukkan bendera, (3) ketahanan otot, kemampuan AUD mempergunakan kekuatan maksimum yang dikerahkan dalam waktu sependek-pendeknya. Gerakan dilakukan dengan perlombaan bergelayutan melewati tangga horizontal dengan tinggi $1,2 \mathrm{~m}$, panjang $1 \mathrm{~m}$, lebar $0,3 \mathrm{~m}$ dengan jumlah anak tangga 5 buah, (4) daya tahan, Kemampuan AUD dalam mempergunakan sistem jantung, paru-paru dan peredaran darah secara efektif dan efisien untuk menjalankan kerja secara terus menerus. Berlari bolak-balik 5 x 10 $m$ dengan memindahkan balok. (5) fleksibilitas, kemampuan AUD untuk menggerakkan persendian dengan melakukan gerak seluas-luasnya. Gerakan yang dilakukan dengan mendorong gambar hewan pada fleksiometer.

Anak usia dini adalah anak usia 0 tahun sampai dengan 8 tahun, pada usia ini terjadi lompatan perkembangan diantaranya adalah pada usia 4 tahun pertumbuhan otak telah mencapai $50 \%$, usia 8 tahun mencapai $80 \%$. PP RI Nomor 27 tahun 1990 Bab 1 Pasal 2 (Ningsih, 2012, p.1), "TK adalah salah satu bentuk pendidikan prasekolah yang menyediakan program pendidikan dini bagi anak usia 4 sampai pendidikan dasar". Pertumbuhan diartikan sebagai perubahan yang bersifat kuantitatif, karena pengaruh luar atau lingkungan, perkembangan merupakan perubahan fungsional yang bersifat kualitatif, baik dari fungsi-fungsi fisik maupun mental berkaitan dengan pengaruh lingkungan 
(Santrock, 2011, p.32). Perkembangan fisik ditujukan agar badan anak tumbuh dengan baik sehingga sehat dan kuat jasmaninya, dengan kesehatan jasmani diharapkan memeroleh jiwa yang sehat. Agar anak tumbuh secara optimal diperlukan makanan bergizi, seimbang, kesehatan yang prima, dan lingkungan yang bersih, serta olahraga. Perkembangan motorik berarti perkembangan pengendalian gerakan jasmaniah melalui kegiatan pusat syaraf, urat syaraf dan otot yang terkoordinasi. Motorik dibagi menjadi dua, motorik kasar (berjalan, berlari, melompat), motorik halus (melempar, menangkap bola, menulis). Geary (2000, p.29) mengatakan perbedaan aktivitas antara laki-laki dan perempuan dipengaruhi faktor budaya ketika anakanak dewasa, anak laki-laki dan perempuan mempunyai sedikit perbedaan bahkan tidak terlihat perbedaan kemampuan fisik. Menurut Sukadiyanto (2012, p.3) dunia anak adalah dunia bermain, artinya semua jenis aktivitas yang ditujukan untuk pengembangan potensi AUD sarana yang digunakan melalui bermain. Pada umumnya aktivitas bermain tentu selalu melibatkan aktivitas jasmani. Untuk itu para guru PAUD perlu mengetahui tentang prinsipprinsip pembelajaran fisik (motorik) yang umumnya dilakukan melalui bermain. Pengalaman gerak yang bermacam-macam (multilateral training) adalah anak-anak diberi kesempatan mengalami berbagai macam pengalaman gerak yang berbeda-beda, misalnya: memanjat, merangkak, merayap, mengguling, meluncur, melompat, menggantung, bermain di air, menarik, mendorong, berjalan dengan tangan, dan sebagainya. Menurut Suyanto (2003, p.140) jenis-jenis permainan meliputi: (1) permainan fisik, (2) permainan lagu anak-anak, (3) permainan teka-teki, (4) permainan dengan benda, dan (5) bermain peran. Tomoliyus (2012, p.10) menyatakan bahwa syarat pembuatan alat aktivitas jasmani yang kreatif dan inovatif adalah edukatif, teknis, dan estetika. Menurut Suyanto (2003, p.9) halaman sekolah didesain dengan baik agar berfungsi sebagai tempat bermain dan belajar anak, alat bermain yang mengembangkan motorik kasar atau otot-otot besar yang diperlukan untuk membentuk fisik anak agar tumbuh dengan baik. Peralatan yang tersedia di PAUD berfungsi untuk mengembangkan kemampuan dasar anak seperti memanjat, keseimbangan, keberanian untuk memanjat, bergelayutan, melempar, berlari, dan menendang diperlukan. Permainan untuk peningkatan latihan kebugaran jasmani (Hinson,
2002, p.25): (1) kekuatan otot; chair curl up, curl down, sit up, ball push up, push up, bear walk, (2) ketahanan otot; biceps curl, overhead press, (3) daya tahan kardiovaskuler; cardio circuit, map reading and run, cycling, swimming, (4) fleksibilitas, set and reach, butterfly. Menurut Fergus (2010, p.35) karakteristik permainan AUD menirukan gerakan binatang (reptilian, mamalia), dan gerakan manusia.

\section{Metode}

Jenis Penelitian

Jenis penelitian ini adalah penelitian dan pengembangan (research and development) melalui survai dengan pengukuran. Penelitian ini merupakan model penelitian yang bertujuan mengembangkan dan memvalidasi produk pendidikan dan pembelajaran untuk meningkatkan dan mengembangkan mutu pendidikan dan pembelajaran secara efektif. Borg and Gall (1983, p.772) mengartikan model penelitian dan pengembangan dalam bidang pendidikan dan pembelajaran sebagai "a process used to develop and validate educational product". Menurut Borg and Gall (1983, p.775) langkahlangkah penelitian pengembangan terdiri atas 10 langkah pelaksanaan yakni sebagai berikut: (a) meneliti dan mengumpulkan informasi, (b) perencanaan, (c) mengembangkan produk awal, (d) uji coba awal, (e) revisi produk utama, (f) uji coba lapangan utama, (g) revisi produk operasional, (h) uji coba produk operasional, (i) revisi produk akhir, (j) diseminasi dan implementasi.

\section{Waktu dan Tempat}

Pra survei dilakukan tanggal 1 Oktober 2012 di 3 TK yaitu, TK Al-Ukhuwah Kalasan, TK ABA As Salam Banguntapan, dan TK YWKA Kota Yogyakarta. Sekolah TK yang ditunjuk adalah yang memiliki halaman untuk melakukan tes kebugaran jasmani AUD (4-6 tahun) tersebar di Provinsi DIY yang terdiri dari Sleman, Bantul, Gunungkidul, Kulon Progo, dan Kota Yogyakarta. Uji skala kecil dilakukan di TK N 2 Sleman tanggal 14 November 2012. Uji skala besar dilakukan di TK Citra Sakti Cangkringan tanggal 30 November 2012 dan TK ABA Cancangan tanggal 7 Desember 2012. Uji lapangan utama di TK di Provinsi DIY. Uji coba lapangan utama dilakukan di 15 TK di Provinsi DIY yang terdiri dari 4 kabupaten dan 1 kota (Kulon Progo, Bantul, Sleman, Gunungkidul dan Kota Yogyakarta). Kabupaten 
Gunungkidul; TK RA Masyitoh Widoro Bunder, TK Kristen Putra Wacana Playen, TK RA Ma'arif Tancep Ngawen, Bantul; TK ABA As Salam Banguntapan, TK Negeri Pembina Bantul, TK Pertiwi Piyungan, Sleman; TK Masjid Kampus UGM, TK Pertiwi Tamanan Kalasan, TK Kanisius Pingitan Minggir, Kulon Progo; TK ABA Dlaban Sentolo, TK Pertiwi Kembangan Nanggulan, TK ABA Boro Galur, dan Kota Yogyakarta; TK YWKA, TK Karangkunti, TK Komplek Masjid Perak, pada tanggal 23 Januari sampai dengan 2 Maret 2013.

\section{Subjek Penelitian}

Populasi dari penelitian ini adalah siswa PAUD di Provinsi DIY. Teknik sampel yang digunakan adalah cluster sampling yaitu untuk menentukan sampel bila objek yang diteliti atau sumber data sangat luas, misalnya penduduk dari suatu negara, provinsi atau kabupaten (Sugiyono, 2007, p.65). Sampel penelitian menggunakan purposive sampling yaitu teknik penentuan sampel dengan pertimbangan tertentu (Sugiyono, 2007, p.68). Siswa PAUD putra dan putri yang berusia 4-6 tahun digunakan sebagai sampel. Jumlah sampel penelitian pada uji skala kecil 10 anak di TK N 2 Sleman. Jumlah sampel penelitian pada uji skala besar 20 anak di TK ABA Cancangan dan TK Citra Sakti Cangkringan. Jumlah sampel penelitian lapangan utama sebanyak 310 orang yang berasal dari 15 TK terdiri dari 4 kabupaten (Sleman, Bantul, Kulon Progo, Gunungkidul), dan satu Kota Yogyakarta. Setiap kabupaten diambil 3 kecamatan dan setiap kecamatan diambil 3 TK berdasarkan kontur daerahnya (perkotaan, pedesaan, gunung, pantai, dataran).

\section{Prosedur Penelitian}

Studi pendahuluan dilakukan dalam dua bentuk, yaitu studi pustaka dan survai terhadap kondisi empirik penelitian. Setelah melakukan kajian teori kemudian melakukan survai lapangan untuk mengetahui kondisi nyata di lapangan sebagai tempat berlangsungnya aktivitas yang menjadi pusat perhatian peneliti.

Studi Pustaka, Setelah fokus masalah diketahui, peneliti memilih, menentukan dan mereview kriteria dari sebuah tes kebugaran jasmani untuk AUD yang baik. Tes yang baik harus valid dan reliabel. Selanjutnya tes tersebut hendaknya ekonomis, praktis, adanya norma penilaian yang dilengkapi petunjuk pelaksanaan dan cara menskor. Tes kebugaran jasmani yang ada adalah mengacu pada tes ke- bugaran jasmani Indonesia tahun 2010. Menganalisis masalah yang disusun dan potensi dari penelitian ini adalah salah satu model tes yang disusun belum pernah ada yang meneliti.

Studi Lapangan, sasaran tes kebugaran jasmani AUD (4-6 tahun) terdiri dari kekuatan otot, ketahanan otot, daya tahan kardiovaskuler dan fleksibilitas. Tes kebugaran jasmani yang sudah ada adalah alat ukur sudah memenuhi syarat dan sahih. Kelemahan dari tes sebelumnya terlalu berat untuk AUD (4-6 tahun) maka dalam penelitian tes disesuaikan dengan karakteristik, dan kemampuan AUD serta memodifikasi dengan permainan dan perlombaan.

Pengembangan Prototipe, setelah model pengembangan berdasarkan studi pendahuluan ditetapkan kemudian dilanjutkan kegiatan menganalisis komponen kebugaran jasmani yang dijadikan butir tes eksperimen, membandingkannya dengan pengetahuan yang ada di literatur.

Selanjutnya menyusun butir-butir instrumen berdasar indikator yang telah ditentukan untuk pengembangan masing-masing variabel. Penyusunan butir disertai dengan penyusunan petunjuk pelaksanaan yang baku dan cara penilaian. Dilanjutkan dengan expert judgment terhadap indikator dan petunjuk pelaksanaan yang baku.

Penilaian dengan expert judgment untuk mengetahui sejauh mana instrumen yang digunakan dalam penelitian telah mencerminkan keseluruhan aspek yang diukur. Expert judgment menggunakan tiga orang ahli yaitu (1) ahli kebugaran jasmani, (2) guru PAUD dan (3) ahli tes, pengukuran dan evaluasi. Kemudian merevisi kembali dari hasil yang telah di expert judgment.

Uji Lapangan, ada empat tahap uji lapangan yang dilakukan secara berurutan yaitu, (1) uji lapangan awal, (2) uji lapangan kecil, (3) uji lapangan besar, (4) uji lapangan utama. Kemudian desain final digunakan untuk mengetes kebugaran jasmani AUD di Provinsi DIY.

Pertama, preliminary field test (uji lapangan awal), peneliti mencoba produk awal pada satu sekolah dengan dua siswa mencatat proses dan hasil selama uji produk yang akan digunakan untuk bahan perbaikan prototipe model.

Kedua, uji lapangan kecil. Uji tahapan ini dilakukan sesuai kebutuhan penelitian. Pada satu sekolah dengan sepuluh siswa mencatat proses dan hasil. Hasil uji lapangan ini akan menjadi bahan untuk merevisi prototipe model 
sebelum menuju pada tahap uji lapangan berikutnya. Uji lapangan kecil ini bertujuan untuk mengetahui tingkat kelayakan proses pelaksanaan model dan dampak atau kemajuan yang diperoleh dari hasil pelaksanaan model tes tersebut.

Ketiga, uji lapangan besar, uji tahap ini dilakukan pada dua sekolah dengan dua puluh siswa mencatat proses dan hasil dilakukan tesretes. Hasil uji kemudian dianalisis nilai efektivitasnya dengan dengan melihat reliabilitas, validitas, mean, dan standar deviasi.

Keempat, desain final, dilakukan tes kebugaran jasmani AUD yang sesungguhnya kepada siswa taman kanak-kanak di Provinsi DIY yang terdiri dari empat kabupaten dan satu kota.

Diseminasi hasil pengembangan adalah tersusunnya sebuah buku petunjuk tes dan norma kebugaran jasmani untuk AUD (4-6 tahun).

Variabel penelitian diidentifikasikan terdiri atas empat variabel yaitu kekuatan otot, ketahanan otot, daya tahan aerobik dan fleksibilitas, untuk mempermudah penyusunan instrumen dan mengintepretasikan tentang hal-hal yang akan diukur.

Instrumen pengumpulan data dalam penelitian ini berupa suatu bentuk tes psikomotorik dari suatu komponen kebugaran jasmani dengan battery test. Sistem battery test karena tes kebugaran tidak boleh dibolak-balik harus urut dari item 1 sampai 4 terdiri dari empat item tes, yaitu: (1) jalan panda 6 meter, (2) bergelayutan di tangga horizontal, (3) lari bolak balik 5 x 10 meter, dan (4) dorong gambar hewan. Adapun dasar untuk uji coba sampel sebagai berikut: (1) Jalan Panda 6 meter, tujuannya untuk mengukur kekuatan otot tangan dan kaki. Lapangan, beton/tegel dilapisi dengan karpet, 2 lintasan, panjang lapangan 6 meter, jarak antar lintasan 30 centimeter. Alat, 2 bendera, 2 kaleng, peluit, 1 stopwatch. Pelaksanaan, 2 anak dengan posisi merangkak, tangan dan kaki sebagai tumpuan di garis start, aba-aba "ya" setiap anak berlomba merangkak mengambil bendera di garis finish dan memasukkannya ke dalam kaleng. Ketentuan, jalan panda masih bisa diulang apabila, peserta mencuri start, peserta tidak melewati garis finish, peserta terganggu oleh peserta lain. Penilaian, anak yang tercepat memasukkan bendera ke kaleng di garis finish yang menang, mencatat hasil waktu setiap anak. Petugas tes, petugas keberangkatan, pengukur waktu merangkap pencatat hasil. (2) Bergelayutan di tangga horisontal, tujuannya untuk mengukur ketahanan otot lengan dan bahu. Alat, tangga horizontal panjang 1 meter lebar 30 centimeter, tinggi tiang penyangga 120 centimeter, jarak antartangga 25 centimeter, matras panjang 1 meter, lebar 0,5 meter (untuk keamanan). Pelaksanaan, anak berdiri di depan tangga, abaaba "Ya" anak mulai bergelayutan dengan memindahkan tangannya melewati setiap anak tangga dari start sampai finish, matras berada di bawah tangga untuk keamanan. Ketentuan, bergelayutan akan diakhiri apabila, peserta tidak mampu melanjutkan bergelayutan atau terjatuh. Penilaian, menghitung jumlah tangga yang dapat dilewati anak, dan anak yang berhasil melewati anak tangga terbanyak yang menang. Petugas tes, menghitung jumlah tang-ga yang dapat dilalui. (3) Lari bolak balik 5 x 10 meter, tujuannya untuk mengukur daya tahan kardiorespirasi. Lapangan, 2 lintasan tegel/beton, panjang lintasan 10 meter, lebar lintasan 1 meter. Alat, 6 balok kecil, 3 tali rafia 10 meter, 6 tempat balok berwarna merah, kuning, dan hijau, peluit dan 1 stopwatch. Pelaksanaan, 2 anak berdiri digaris start, setelah aba-aba "Ya" anak berlari memindahkan 3 balok bolak balik dari start ke finish dimasukkan ke kotak sesuai warna balok, setelah memindahkan 3 balok anak berhenti berlari. Ketentuan, lari masih bisa diulang apabila; peserta mencuri start, peserta tidak melewati garis finish, peserta tidak menyelesaikan mengambil balok, peserta terganggu oleh peserta lain. Penilaian, anak yang tercepat memindahkan balok dari start ke finish yang menang, mencatat hasil waktu setiap anak. Petugas tes, petugas keberangkatan pengukur waktu merangkap pencatat hasil. (4) Mendorong gambar hewan, tujuannya untuk mengukur kemampuan otot dan sendi. Alat, fleksiometer modifikasi panjang 0,5 meter, lebar 0,3 meter, tinggi 32 centimeter, gambar binatang untuk didorong ke depan mistar. Pelaksanaan, anak duduk selunjur tanpa alas, kaki menempel pada tumpuan fleksiometer, tangan menjulur ke depan, ujung jari mendorong gambar binatang ke depan sampai jangkauan maksimal. Ketentuan, mendorong hewan masih bisa diulang apabila, peserta mencuri start, belum diukur pada saat tangan ke depan sebelum mendorong, peserta menekuk kaki, peserta terganggu oleh peserta lain. Penilaian, diukur jarak maksimal yang mampu dicapai ketika mendorong gambar binatang. Petugas tes, petugas pemeriksa kelurusan kaki tangan, petugas pencatat hasil.

Setiap testi melakukan 4 macam item tes dengan modifikasi tes yang telah dibuat. 
Selanjutnya, hasil dari Tes kebugaran jasmani (kekuatan otot, ketahanan otot, daya tahan kardiovaskuler dan fleksibilitas) dicari validitas dan reliabilitas untuk menentukan keajekan alat. Mean dan standar deviasi untuk menentukan norma item setiap tes. Tes yang dipilih adalah hasil dari data uji coba yang memiliki standar deviasi yang kecil.

Teknik pengumpulan data adalah caracara yang dapat digunakan oleh peneliti untuk mengumpulkan data. Sebelum pengumpulan data, tes kebugaran jasmani AUD (4-6 tahun) disusun oleh peneliti yang telah disetujui oleh tim ahli. Adapun tim ahli terdiri dari seorang ahli dalam kebugaran jasmani AUD yaitu Prof. Dr. Sukadiyanto, M.Pd, seorang ahli evaluasi, tes dan pengukuran olahraga yaitu Dr. Tomoliyus, MS.

Metode pengumpulan data yang digunakan dalam penelitian ini menggunakan metode battery test (tes urut, terus menerus tidak boleh dibalik) Castillo (2009, p.4). Tujuan penggunaan metode tersebut untuk memperoleh informasi yang relevan dengan tujuan penelitian dan validitas serta reliabilitas instrumen. Jenis data berupa data kuantitatif yang diperoleh dari pemberian skor masing-masing butir dalam tes kebugaran jasmani AUD yang diujicobakan.

Jenis data yang dikumpulkan adalah data kuantitatif dengan pemberian skor masingmasing butir tes kebugaran jasmani AUD yang diujikan yaitu tes kekuatan otot, ketahanan otot, daya tahan kardiovaskuler dan fleksibilitas. Jumlah petugas pengumpul data terdiri dari 2-5 orang dengan kualifikasi mahasiswa PPs Ikor, mahasiswa FIK dan alumni FIK karena lebih memahami tentang penelitian tes kebugaran jasmani dan guru TK membantu dalam mencatat hasil tes. Sebelum dan sesudah pengambilan data dilakukan koordinasi tentang penjelasan dan pembagian tugas. Jadwal waktu pelaksanaan pengambilan data dilakukan pada tanggal 23 Januari 2013 sampai 2 Maret 2013.

Analisis data adalah proses mencari dan menyusun secara sistematis data yang diperoleh dari hasil wawancara, catatan lapangan, dan bahan-bahan lain sehingga mudah dipahami.

Pertama, Uji deskriptif digunakan untuk menganalisis data dengan cara mendeskripsikan atau menggambarkan data yang telah terkumpul sebagaimana adanya tanpa bermaksud membuat kesimpulan yang berlaku untuk umum. Uji deskriptif dilakukan pada saat uji pra survei, expert judgment.

Kedua, Uji varian dengan battery test untuk mengetahui reliabilitas dan validitas alat yang digunakan untuk tes. Menggunakan SPSS 16 (Donoghue, 2012, p.1). Signifikansi sebesar 0,01, artinya Angka hasil hitung komputer yang didapat dari analisis statistik lebih besar dari angka standar taraf signifikan 0,01 maka dikatakan bahwa korelasi signifikan.

Ketiga, Uji deskriptif statistik, untuk mencari nilai minimum, maksimum, standar deviasi. Hasilnya akan digunakan untuk mencari panjang kelas, kelas interval, dan uji $\mathrm{Z}$ (Donoghue, 2012, p.94).

Keempat, Cara menyusun norma tes, dari data mentah dimasukkan ke program excel 2007 untuk mengurutkan nilai data tertinggi sampai data terendah, kemudian dimasukkan dalam program SPSS 16 untuk mencari nilai maksimum, minimum, mean, standar deviasi, dan uji z, kemudian didapat nilai konversi uji z. Hasil konversi nilai uji z digunakan dalam klasifikasi nilai range dan panjang kelas untuk setiap item tes, kemudian nilai di total dari item 1 sampai item 4 untuk mengklasifikasi kategori kurang sekali, kurang, sedang, baik, baik sekali.

\section{Hasil Penelitian dan Pembahasan}

Uji Validitas setiap Item

Pada uji korelasi dengan menghitung setiap item tes didapat hasil sebagai berikut, (1) tes jalan panda 6 meter; 0,997, (2) tes bergelayutan di tangga horizontal; 0,942, (3) tes lari 50 meter; 0,994, dan (4) tes dorong gambar hewan; 0,975 . Reliabilitas dari 4 item sebagai berikut, (1) tes jalan panda 6 meter; 0,936, (2) tes bergelayutan di tangga horizontal; 0,906, (3) tes lari 50 meter; 0,935 , dan (4) tes dorong gambar hewan; 0,926. Hasil nilai hitung data lebih tinggi dari nilai standar taraf signifikan 0,01 maka data dinyatakan signifikan.

\section{Uji Validitas Battery Test}

Pada uji korelasi dengan battery test terdiri dari empat item tes, yang digabungkan antara nilai total uji z tes dan uji z retes, didapat hasil sebagai berikut, validitas 0,982 dan reliabilitas 0,930 . Hasil nilai hitung data lebih tinggi dari nilai standar taraf signifikan 0,01 maka data dinyatakan signifikan. 
Penyusunan Hasil Nilai dan Norma Kesegaran Jasmani

Tabel 1. Tabel Nilai Tes Kebugaran Jasmani untuk Anak Usia Dini (4-6 tahun)

\begin{tabular}{cccccc}
\hline Nilai & Jalan Panda 6 m & Bergelayutan & Lari 50 m & Dorong Hewan (cm) & Nilai \\
\hline 5 & dst $-4.41^{\prime \prime}$ & 5 & dst $-19.21^{\prime \prime}$ & dst 22.40 & 5 \\
4 & $4.42^{\prime \prime}-5.41^{\prime \prime}$ & 4 & $19.22^{\prime \prime}-20.57^{\prime \prime}$ & $22.39-19.29$ & 4 \\
3 & $5.42^{\prime \prime}-6.41^{\prime \prime}$ & 3 & $20.58^{\prime \prime}-21.93^{\prime \prime}$ & $19.28-16.18$ & 3 \\
2 & $6.42^{\prime \prime}-7.41^{\prime \prime}$ & 2 & $21.94^{\prime \prime}-23.29^{\prime \prime}$ & $16.17-13.07$ & 2 \\
1 & $7.42^{\prime \prime}-\mathrm{dst}$ & 1 & $23.30^{\prime \prime}-\mathrm{dst}$ & $13.06 \mathrm{dst}$ & 1 \\
\hline
\end{tabular}

Tabel 2. Norma Tes Kebugaran Jasmani untuk Anak Usia Dini (4-6 tahun)

\begin{tabular}{ccc}
\hline No & Jumlah nilai & Klasifikasi \\
\hline $\mathbf{1}$ & $20-18$ & BAIK SEKALI (BS) \\
$\mathbf{2}$ & $15-17$ & BAIK (B) \\
$\mathbf{3}$ & $12-14$ & SEDANG (S) \\
$\mathbf{4}$ & $9-11$ & KURANG (K) \\
$\mathbf{5}$ & $\leq 8$ & KURANG SEKALI (KS) \\
\hline
\end{tabular}

Tabel 3. Persentase Hasil Tes Kebugaran Jasmani untuk Anak Usia Dini (4-6 tahun)

\begin{tabular}{cccll}
\hline No & Jumlah nilai & Klasifikasi & Persentase & Jumlah \\
\hline $\mathbf{1}$ & $20-18$ & BAIK SEKALI (BS) & $5,80 \%$ & 18 orang \\
$\mathbf{2}$ & $15-17$ & BAIK (B) & $25,16 \%$ & 80 orang \\
$\mathbf{3}$ & $12-14$ & SEDANG (S) & $37,41 \%$ & 116 orang \\
$\mathbf{4}$ & $9-11$ & KURANG (K) & $26,13 \%$ & 81 orang \\
$\mathbf{5}$ & $\leq 8$ & KURANG SEKALI (KS) & $4,81 \%$ & 15 orang \\
\hline
\end{tabular}

\section{Persentase kebugaran jasmani AUD (4-6 tahun) di Provinsi DIY}

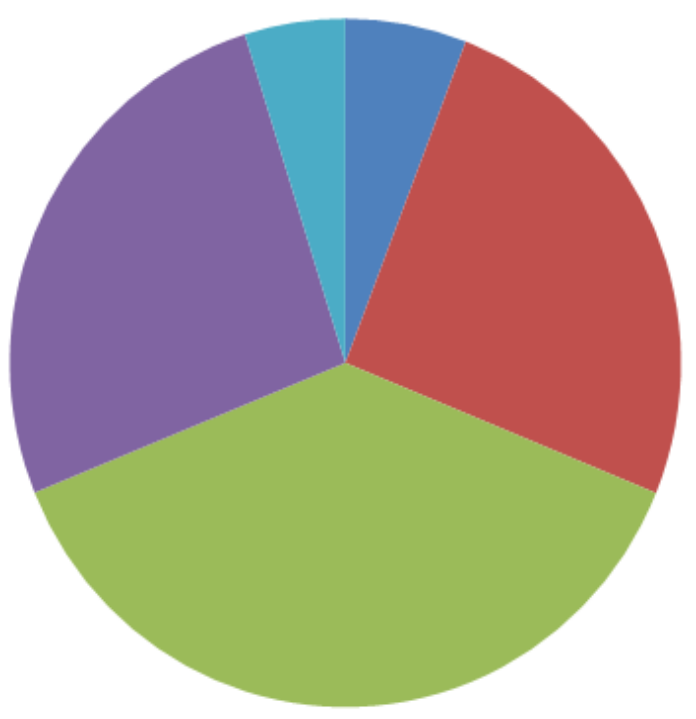

-BAIK SEKALI

$\square$ BAIK

SEDANG

- KURANG

"KURANG SEKALI (KS)

Gambar 1. Persentase Hasil Tes Kebugaran Jasmani Untuk Anak Usia Dini (4-6 tahun)

\section{Simpulan dan Saran}

Simpulan

Berdasarkan hasil penelitian yang telah diuraikan pada pembahasan, dapat diambil suatu kesimpulan bahwa telah disusun tes dan norma kebugaran jasmani untuk anak usia dini (4-6 tahun) dengan hasil valid, reliabel, dan sesuai dengan karakter AUD, rangkaian tes dapat digunakan sebagai alat tes.

Rangkaian tes terdiri atas 4 bentuk tes menggunakan battrey test, adapun rangkaian tes kebugaran untuk anak usia dini antara lain; (1) jalan panda 6 meter, (2) bergelayutan di tangga horisontal, (3) lari bolak balik $5 \times 10 \mathrm{~m}$, (4) dorong gambar hewan. Data dinyatakan valid 
dan reliabel karena nilai hitung lebih besar dari nilai standar signifikan 0,01 dengan hasil nilai reliabilitas; 0,930 dan nilai validitas; 0,982 . Desiminasi penelitian adalah tersusun buku pedoman tes kebugaran jasmani untuk anak usia dini (4-6 tahun).

Hasil penelitian menunjukkan bahwa AUD di daerah pedesaan mempunyai kebugaran yang lebih baik dari AUD di perkotaan.

Saran

Tes kebugaran jasmani untuk AUD diharapkan dapat memberikan sumbangan dan referensi kepada guru taman kanak-kanak dalam pemberian nilai kebugaran jasmani fisik motoris. Alat tes kebugaran jasmani yang tersusun dapat digunakan sebagai alat tes untuk menilai kebugaran jasmani AUD (4-6 tahun) karena memiliki validitas dan reliabilitas yang memadai. Permasalahan kebugaran jasmani pada usia 4-6 kurangnya aktivitas jasmani AUD karena moderenisasi semua serba mudah, maka sebagai acuan guru dalam meningkatkan kebugaran jasmani siswa AUD (4-6 tahun) lebih berkualitas.

\section{Daftar Pustaka}

Borg, W. R., \& Gall, M. D. (Eds.). (1983). Educational research. New York: Longman Inc

Castillo, M J. (2009). The alpha health-related fitness test battery for children and adolescents. Granada: university of Granada. Diambil pada tanggal 30 Oktober 2012 dari www.thealphaproject.net.

Departemen Pendidikan Nasional Kesegaran Jasmani dan Rekreasi. (2010). Tes kebugaran jasmani Indonesia untuk umur 6-19 tahun. Jakarta, 2010. Pusat kesegaran jasmani dan rekreasi: Departeman pendidikan nasioanal.

Donoghue, P. (2012). Statistik for sport and exercise studies. New York: Routledge.

Fergus, H.P. (2010). Children, play, and development. London: Sage.

Geary, C.D. (August 2000). Evolution and developmental sex differences. The Psychological Science, 7, 29-31.
Irianto, Djoko P. (2004). Pedoman praktis berolahraga untuk kebugaran dan kesehatan. Yogyakarta: Andi Offset.

Ningsih, Nuwu. (April 2012). Cara pengkondisian TK dalam pembelajaran fisik/ motorik. Makalah disajikan pada Pelatihan Pembelajaran Fisik/Motorik Anak Usia Dini Se DIY, di Universitas Negeri Yogyakarta.

Nurcahyo, Heru. (2008). Ilmu kesehatan: Untuk SMK $(2 r d)$. Jakarta: Dikmenjur.

Lutan, Rusli. (2001). Pengukuran dan evaluasi pendidikan jasmani. Bandung: Depdikbud.

Ruis Jonatan, Castro Penero \& Doe. (2011). Field-based fitness assessment in young people: the ALPHA health-related fitness test battery for children and adolescents [Versi electronik]. Journal, $1,1-2$.

Santrock, J.W. (2011). Perkembangan anak. (Terjemahan Verawati Pakpahan dan Wahyu Anugraheni). Jakarta Salemba Humanika. (Buku asli diterbitkan tahun 2009).

Sugiyono. (2007). Statistika untuk penelitian (Rev. ed.). Bandung: Alfabeta.

Sukadiyanto. (April 2012). Prinsip pembelajaran fisik/motorik pada anak usia dini. Makalah disajikan pada Pelatihan Pembelajarn Fisik/Motorik Anak Usia Dini Se DIY, di Universitas Negeri Yogyakarta.

Suyanto, Slamet. (2003). Konsep dasar pendidikan anak usia dini. Yogyakarta: UNY.

Tim Penyusun Kamus Pusat Bahasa. (2007). Kamus besar bahasa Indonesia (KBBI). Jakarta: Balai Pustaka.

Tomoliyus. (April 2012). Pembuatan alat aktivitas jasmani edukatif, kreatif dan inovatif berbasis budaya dan lingkungan untuk anak TK. Makalah disajikan pada Pelatihan Pembelajarn Fisik/Motorik Anak Usia Dini Se-DIY, di Universitas Negeri Yogyakarta. 